\title{
Perceptions of affirmative action: an empirical study
}

\author{
Trevor Amos, ${ }^{\prime *}$ Richard Scott, J. William² \\ Department of Management, Rhodes University, Grahamstown, 6140 Republic of South Africa \\ Judith Scott ${ }^{3}$ \\ Department of Marketing, Metropolitan State College, Denver, Colorado 80217, United States of America
}

\author{
Received June 1996
}

\begin{abstract}
Private and public South African employers have instituted affirmative action policies meant to provide employment opportunities to Black South Africans. A body of literature suggests that because of affirmative action policies Black hopes have been raised while Whites view such policies as having a negative impact on their opportunities. However, no extant literature details an empirical investigation of these suggestions. Therefore, this study focusses on the affirmative action perceptions held by 350 South African university commerce students.
\end{abstract}

Suid-Afrikaanse werkgewers van beide die private en die openbare sektore het ' $n$ beleid van regstellende aksie in werking gestel met die doel om werksgeleenthede aan Swart Suid-Afrikaners te verskaf. ' $n$ Verskeidenheid navorsingsliteratuur gee voor dat die proses aanleiding gegee het tot verhoogte verwagtings onder Swart Suid-Afrikaners, terwyl Blanke SuidAfrikaners sulke optrede as nadelig vir hul werksgeleenthede beskou. Nietemin blyk dit dat geen navorsingsliteratuur wat op ervaring gegrond is eintlik voor die hand liggend is nie. Die klem van hierdie studie val dus op die persepsies van 350 Suid-Afrikaanse studente in die ekonomiese en bestuurswetenskaplike veld ten opsigte van regstellende aksie.

*Author to whom correspondence should be addressed.

\section{Introduction}

Relative to its southern African neighbours the Republic of South Africa is an economic dynamo. South Africa's prowess is evidenced by comparing its economic activity with that of its eleven fellow member states of the Southern African Development Community (SADC) - Angola, Botswana, Lesotho, Malawi, Mauritius, Mozambique, Namibia, Swaziland, Tanzania, Zambia, and Zimbabwe. Such a comparison shows, according to the Daily Dispatch (1995), that South Africa's national budget, currently about $30 \%$ of its Gross Domestic Product (GDP), is about as large as the total GDP of the other eleven members of the SADC combined. Further, South Africa's GDP per capita is more than twice as high as the next best country, Mauritius, and about 25 times greater than the SADC member state with the lowest, Mozambique.

\section{Employment and income distribution .}

With the above economic indicators in hand, a casual observer would likely regard South Africa's economy as rich and robust. Compared to other sub-Saharan countries it is. But as any student of economics knows, statistics often do not paint a true portrait of a nation's wealth, especially when analysing how wealth is distributed. Distribution of jobs and income among its racial/ethnic groups is where South Africa has a big problem.

Shortly after he was released from prison in early 1990 , Nelson Mandela candidly observed, 'You say (the South African economy) is inherently strong. How can that be when it fails to employ half of those who wish to work?' The problem seems to be even more acute than Mandela's observation. In fact, according to the Financial Mail (1994: 6) about $80 \%$ of South Africa's Black population is unemployed (as used here the term 'Black' includes Africans, Coloureds [people of mixed race], and Asians that is, all non-whites.) Also, according to the same edition of the Financial Mail, if current trends continue, for every ten young Blacks who enter the formal job market, less than one of those will succeed in finding a job.

Supporting this contention is 1993 research reported by the South African Institute for Race Relations (1994), which details that three million (52\%) of the people between the ages of 16 and 30 years who were able to work were not employed. Altogether $57 \%$ of Black South Africans, $46 \%$ of young Coloured people, $17 \%$ of young Indians and $4 \%$ of young Whites fell into this category. It should be kept in mind, however, that South Africa has no comprehensive system for the registration of unemployment, which means that there is no true measure with respect to the extent of unemployment in the country.

Any discussion concerning South Africa's employment and income distribution problems requires some information about its demographics. In that vein, South Africa's total population is just over 40 million. Of this total, $76.1 \%$ is Black, $12.8 \%$ White, $8.5 \%$ Coloured, and $2.6 \%$ is Asian. Personal disposable income (personal income less direct taxes) for Whites is $48.9 \%, 38.3 \%$ for Blacks, Coloureds $8.9 \%$, and for Asians, 3.9\%. Measured against White income, the average Asian will receive $49 \%$ of the average White's income, the average Coloured 27\%, and the average Black 13\% (Bureau of Market Research, 1994).

With respect to the representation of these groups in managerial positions, a study of 70 large companies, whose combined workforce represents nearly 700000 employees, found that Whites occupied $93.34 \%$ of all management positions, Blacks $2.5 \%$, Coloureds $2.02 \%$, and Asians $2.14 \%$ (Bowmaker-Falconer \& Horwitz, 1994).

\section{Interim constitution and affirmative action}

Inequality between White South Africans and other racial and ethnic groups pinpoint the width of the gulf between the grinding poverty of most of South Africa's non-white population and the massive wealth owned by its White citizens. This is nearly as true today as it was 25 years ago. 
For example, in 1970, approximately $20 \%$ of the population (mainly White South Africans and a small group of nonwhites) owned $75 \%$ of the nation's wealth, compared with $62 \%$ in Brazil and $39 \%$ in the Unites States. Later. South Africa's Gini coefficient (which measures inequality) was the highest of any of the 57 countries in the world for which data were available (Wilson \& Ramphele, 1989).

Recognizing the dismal state of the distribution of employment and income among its racial/ethnic groups, South African political leaders have made an effort recently to write the concept of equal treatment into the country's interim constitution. For example, opening with a preamble proclaiming the need to 'create a new order' that ensures 'equality between men and women of all races', the 220 page constitution covers such subjects as 'fundamental rights' in employment.

Ratified by the nation's parliament in December 1993, the interim constitution laid the foundation for the official sanction of 'affirmative action' in employment. Specifically, paragraphs $8(2)$ and $8(3)(a)$ of Chapter 3 (Fundamental Rights) of the constitution states:

8.(2) No person shall be unfairly discriminated against, directly or indirectly, and, without derogating from the generality of this provision, on one or more of the following grounds in particular: race, gender, sex, ethnic or social origin, colour, sexual orientation, age, disability, religion, conscience, belief, culture or language.

8.(3)(a) This section shall not preclude measures designed to achieve the adequate protection and advancement of persons or groups or categories of persons disadvantaged by unfair discrimination, in order to enable their full and equal enjoyment of all rights and freedoms - emphasis added (Historic Documents of 1993, 1994).

Despite the wording of the interim constitution, the government of South Africa has yet to issue guiding regulations or policies on affirmative action. That has not, however, precluded the South African Chamber of Business (SACOB) from adopting precedent-setting policies for its member organizations. From research commissioned by SACOB it was concluded that affirmative action in the business sector is necessary and desirable. Among the reasons given for this is the need for occupational reform to keep pace with political empowerment (South African Chamber of Business, 1995).

\section{Black hopes}

Although no existing research indicates this, the hopes of Black South Africans have obviously been uplifted by the government's constitutional provision and by employer initiatives that are making affirmative action employment a reality. This is in spite of the fact that the South African government has not issued affirmative action regulations or policies. There appears to be, however, widespread employer acceptance of the view that affirmative action should be implemented to address socio-economic inequalities. This proactive mode may have been generated by such thinking as,

'We knew if we didn't start early enough on our own to promote more Blacks into skilled and management positions it would be forced on us' (quote attributed to a 'manager') (Collins. 1994).
Referring to a survey completed by the South African stock exchange, Collins (1994) reports that $38 \%$ of engineering companies have affirmative action policies in place, while $61 \%$ see the need for such policies. More recently it has been reported that the number of South African companies implementing affirmative action at top executive levels since 1994 has increased dramatically. For example, of more than 1000 companies surveyed in $1995,77 \%$ had some form of affirmative action policy at their executive levels compared to only 53.3\% in 1994 (Mail \& Guardian, 1995). Further, a recent survey by a management consulting firm indicated that $84 \%$ of the 86 public and private organizations surveyed had some form of affirmative action policies in place. This is compared to $74 \%$ in 1993 and $58 \%$ in 1992 (Caldwell, 1995).

While the affirmative action policies of commercial enterprises may vary, it is likely that many contain an affirmative action goal such as that expressed in the policy of Edgars Stores, Lid., a South African retailer. This corporation's goal is:

'(B)y the year 2000, the "employee mix" in the Edgars Group will accurately reflect the population groups of the country. This in effect means that the company will become $80 \%$ Black. ${ }^{4}$ Priority will be given to African Blacks, then Coloureds and Asians' (Edgars Stores, Lid., 1995).

Many of South Africa's largest employers have also targeted Blacks for recruitment and promotion. For example, in a 1994 study of 70 major South African employers. it was noted that new hire percentages (as a percentage of total recruitment) were $26.7 \%$ for Whites, Blacks $61.6 \%$, Coloureds $9 \%$, and Asians $2.7 \%$. With respect to promotions, the same study revealed that as a percentage of total promotions, Whites received $26.7 \%$, Blacks $54.09 \%$, Coloureds $8.86 \%$, and Asians 3.6\% (Bowmaker-Falconer \& Horwitz, 1994). On the face of these private sector statistics, given the prior make-up of the employment picture, it appears that Blacks are making some headway in landing jobs and climbing the career ladder.

Some elements in the public sector have also established af firmative action policies. For example, the Suuth African Water Affairs \& Forestry Ministry established an 'Employment Equity Policy' in 1995. This ministerial policy directive includes the setting of 'numerical goals' for hiring, training and promotion. In explicit language the policy further imposes affirmative action compliance on the suppliers of goods and services to the ministry by suggesting that they implement a similar policy (Financial Mail, 1995).

Going considerably further than most other private or public organizations, the Black Management Forum (BMF), a group of Black South African business professionals, sets forth specific managerial-level affirmative action targets for South African economic sectors by the year 2000 . To meet the BMF targets, Blacks must occupy: $50 \%$ of all board seats, $30 \%$ of senior management positions, $40 \%$ of middle management positions, $50 \%$ of junior management positions, $70 \%$ of all supervisory positions, and $80 \%$ of all remaining positions (People Dynamics, 1994). 


\section{White fears}

Against the backdrop of the gathering momentum to instil the doctrine of affirmative action in South African employers, many Whites probably feel somewhat disadvantaged. In fact, they may be vibrating from the anxiety produced by such a new concept. In the past, after all, whites were the primary beneficiaries of job opportunities, upward mobility, and higher income levels as contrasted to their racial/ethnic contemporaries. Previous, many White South Africans must have held beliefs such as a former leader of the Trades Union Council of South Africa (TUCSA), put it:

'TUCSA demands equal pay for equal work but does not support the major demands of all non-white workers, that they should have equal opportunities as well (Davies, O'Meara \& Dlamini, 1988).

\section{Reverse discrimination}

Today, it is highly unlikely that most Whites would deny equal employment opportunity to any of their fellow South African citizens, regardless of race or ethnicity. Yet, at the same time, Whites do not want to be discriminated against either. That is why it is questionable whether or not the concept of South African-style affirmative action programmes with numerical quotas by racial/ethnic groups - will meet with any enthusiasm among the White population. While there is no extant research to prove it, many White South Africans probably agree with controversial author, Don Caldwell, who writes:

'(A)ffirmative action leads to unintended (but easily predictable) consequences. It increases group conflict, as resentment by the punished groups grows and the demands of the beneficiaries increase. It emphasises group differences, rather than eliminating them. It discourages effort by the beneficiaries, who come to expect special privileges. And it destroys equality at law (Enterprise, 1992).

Without a doubt the concept of affirmative action is controversial and frightening to many White South Africans. That number would likely regard affirmative action as reverse discrimination which they may feel will place the criterion of race before that of merit (South African Institute for Race Relations, 1994). Such feelings may have been formed by factors such as a position announcement for a 'General Manager Designate' for the Fidelity Guards Holdings (Pty) Ltd. This announcement specified that 'applicants for this position will be considered if they meet the following criteria: Black South African, in possession of a Business Management Degree, preferably in the 38 to 45 year age bracket, et cetera' - emphasis added (advertisement appearing in the Weekend Post, August 11, 1995). In other words, according to the announcement, Whites need not apply.

In a recent best-selling book by a Black South African, 'fear of affirmative action' was underscored by the author as the number one fear of White South Africans. Although providing no documentary evidence to support his claim, the author claims the fear of affirmative action is greater than previous White fears with respect to a Blackled South African government (Mbigi, 1995: 57).

Although it is likely that affirmative action concepts have uplifted the expectations of most Black South Africans, it is unclear what actual gains they will achieve, as a group, in terms of job opportunity and salary equity. A recent article by Castle (1995) suggests that a majority of Blacks may actually experience very little change with respect to income redistribution. Her article reviewed extant affirmative action litera. ture gleaned from the experiences of Zimbabwe, Namibia and Malaysia - developing countries, such as South Africa, in which the majority group now wields political power. Her findings reveal that

'at national levels, affirmative action is shown to favour the redistribution of wealth and status between racial groups, but not within these groups, resulting in the growth and power of new elite groups' (Castle, 1995).

\section{White flight}

In nearly every forum where White South Africans gather socially, the authors of this study have noted that discussions often turn to the topic of affirmative action and to the recourse left to them as to how they might deal with it. What generally follows is talk about emigration. And, it appears that although many Whites who engage in these discussions seemingly have secure positions themselves; their voiced concern usually focusses on the perception that their children will be left out in the cold when the time comes for them to seek employment in the new South Africa.

Emigration by Whites from South Africa is a problem. In 1992, for example, the Central Statistical Service (CSS) reported that 4289 South Africans (read 'White') left the country. Of these, more than $25 \%$ were in professional, technical, and executive positions. It has been pointed out, however, that actual numbers may be much higher because CSS cannot record those professionals who left the country as tourists, yet did not return to the country because they had, in fact, emigrated (South African Institute of Race Relations, 1994: 475). More recent data suggests that the problem may be becoming critical when it was reported that 340 engineers left the country in 1994 (Weekend Post, 1995).

More evidence concerning White flight as a way to thwart affirmative action policies is evidenced by research undertaken by the Human Sciences Research Council (HSRC). Their study revealed that $12 \%$ of Whites had strongly considered emigrating. Further, the study found that $23 \%$ of Whites between the ages of 18 and 49 had given some thought to emigrating (South African Institute for Race Relations, 1994: 93).

\section{Youth focus of research}

Until this point the authors of this study have provided the reader with a review of relevant literature with, admittedly, some conjecture interspersed within the narrative. It should be noted that most of the data presented heretofore has focussed on those South Africans who have jobs or who are now seeking employment. However, young people preparing to enter the world of work are seldom passive observers to events occurring in the workplace that may impact on their job opportunities. Therefore, this empirical research will focus on a sample of those youth who are now in pursuit of their university degrees but will be looking for jobs in the near future. 


\section{Research question}

It is felt that the use of a societal sample of university students for the research conducted affords the opportunity of presenting the views of an important sector of the community today's university graduates being broadly regarded as tomorrow's leaders.

Indeed, university students are often viewed as the avant garde of society. In this light the university setting has always been a place of tension. Tension around the campus tends to heighten when students begin to contemplate how they will live after obtaining their hard-earned degrees. Bottomline questions for these students are: will I get a job, will it pay enough? Beyond these questions, all else seems moot. Therefore, the research questions for this study are: how do university students of all racialethnic groups perceive affirmative action as impacting upon their job opportunities in the new South Africa?

\section{Methods}

\section{Instrument}

A questionnaire was devised to gather data to answer the above-stated research yuestions. It comprised two sections. The first section queried respondents as to their demographic characteristics (gender, age, race/ethnicity, university level, study area, parent(s) incomes, occupation of household head, education level of parent(s), and the occupation the student planned to engage in). The second section focussed on respondent perceptions of the work place in general, followed by specific questions as to the perceived role that affirmative action would play in their careers. The instrument was based mainly on a previous study by Scott, Nelson \& Scott (1988), although the affirmative action component was added for this study. The research instrument is included as Appendix 1 to this study.

\section{Statistical procedures}

Individual questionnaires were used as input data into a 1990 Bio-Medical Data Processing (BMDP) statistical software package. The data set was cross-tabulated by gender, race/ ethnicity, and educational level. Cross-tabulations were also treated by Pearson Chi-Square techniques and, where necessary, by Yates Corrected Chi-square. For the purpose of this study, the obtained data set will be discussed in terms of either the actual number of respondents, or as a percentage of the total respondents.

\section{Sample}

Altogether $352^{5}$ Rhodes University commerce students participated in the study in the course of August 1995. Of the total number of participants, 149 were Blacks, 142 Whites, seven Coloureds, 36 Asians, and three respondents classified themselves as 'other'. For purposes of this article, respondents who classified themselves as Colouered, Asian or 'other' are grouped into the category Coloured. A percentage demographic profile of the sample by gender (Table 1), university year of study (Table 2), and degree major (Table 3), is provided.
Table 1 Gender profile of study sample (by ethnicity, observed frequency and percentage of respondents)

\begin{tabular}{lcccc}
\hline Gender & Black & White & Coloured & Total \\
\hline Male & 81 & 86 & 25 & 192 \\
& $54.4 \%$ & $60.6 \%$ & $54.3 \%$ & $57.0 \%$ \\
Female & 68 & 56 & 21 & 145 \\
& $45.6 \%$ & $39.4 \%$ & $45.7 \%$ & $43.0 \%$ \\
\hline Total & 149 & 142 & 46 & 337 \\
& $100 \%$ & $100 \%$ & $100 \%$ & 100 \\
\hline
\end{tabular}

Table 2 Year of study profile of study sample (by ethnicity, observed frequency and percentage of respondents)

\begin{tabular}{lcccc}
\hline Year of study & Black & White & Coloured & Total \\
\hline First year & 82 & 67 & 16 & 165 \\
& $55.0 \%$ & $47.2 \%$ & $34.8 \%$ & $49.0 \%$ \\
Second year & 44 & 36 & 11 & 91 \\
& $29.5 \%$ & $25.4 \%$ & $23.9 \%$ & $27.0 \%$ \\
Third year & 20 & 37 & 18 & 75 \\
& $13.4 \%$ & $26.1 \%$ & $39.1 \%$ & $22.3 \%$ \\
Honours & 3 & 2 & 1 & 6 \\
& $2.0 \%$ & $1.4 \%$ & $2.2 \%$ & $1.8 \%$ \\
\hline Total & 149 & 142 & 46 & 337 \\
& $100 \%$ & $100 \%$ & $100 \%$ & $100 \%$ \\
\hline
\end{tabular}

Table 3 Degree major profile of study sample (by ethnicity, observed frequency and percentage of respondents)

\begin{tabular}{lcccc}
\hline Degree major & Black & White & Coloured & Total \\
\hline Management & 36 & 58 & 15 & 109 \\
& $24.7 \%$ & $41.1 \%$ & $34.1 \%$ & $32.9 \%$ \\
Accounting & 50 & 31 & 18 & 99 \\
Info systems & $34.2 \%$ & $22.0 \%$ & $40.9 \%$ & $29.9 \%$ \\
Economics & 26 & 17 & 3 & 46 \\
& $17.8 \%$ & $12.1 \%$ & $6.8 \%$ & $13.9 \%$ \\
Law & 9 & 13 & 2 & 24 \\
& $6.2 \%$ & $9.2 \%$ & $4.5 \%$ & $7.3 \%$ \\
Psychology & 10 & 8 & 2 & 20 \\
& $6.8 \%$ & $5.7 \%$ & $4.5 \%$ & $6.0 \%$ \\
Other & 11 & 11 & 3 & 25 \\
& $7.5 \%$ & $7.8 \%$ & $6.8 \%$ & $7.6 \%$ \\
\hline Total & 4 & 3 & 1 & 8 \\
& $2.7 \%$ & $2.1 \%$ & $2.3 \%$ & $2.4 \%$ \\
\hline & 146 & 141 & 44 & 331 \\
& $100 \%$ & $100 \%$ & $100 \%$ & $100 \%$ \\
\hline
\end{tabular}

\section{Findings}

Table 4 shows a relatively high degree of optimism towards job availability by all racial/ethnic groups represented in the respondent sample. Whites, however, expressed the highest level of pessimism $(35.9 \%)$ although still more than half $(64.1 \%)$ of the White respondents felt optimistic about the 
Table 4 Perception as to the number of jobs available (by ethnicity, observed frequency and percentage of respondents)

\begin{tabular}{lcccc}
\hline \# of jobs & Black & White & Coloured & Total \\
\hline Optimistic & 122 & 91 & 33 & 246 \\
& $83.0 \%$ & $64.1 \%$ & $71.7 \%$ & $73.4 \%$ \\
Pessimistic & 25 & 51 & 13 & 89 \\
& $17.0 \%$ & $35.9 \%$ & $28.3 \%$ & $26.6 \%$ \\
\hline Total & 147 & 142 & 46 & 335 \\
& $100 \%$ & $100 \%$ & $100 \%$ & $100 \%$ \\
\hline
\end{tabular}

number of jobs that will be available to them. The data has a chi-square value of 13.316 which is significant at the 0.0013 level.

It is interesting to note that with respect to opportunities (see question 11 in the research instrument in the appendix that asked: 'Compared to your parent(s), do you feel you have the [same, more, less, don't know] opportunities that they had?') the vast majority of the sample perceived that their opportunities would be greater than their parents. To illustrate, 95.3\% of the Coloureds and $87.4 \%$ of Blacks concluded the number of opportunities open to them would be greater than had been available to their parent(s). Although $53.6 \%$ of White respondents felt they would have more opportunities than their parent(s), $28.6 \%$ felt they would have less.

Table 5 clearly shows that most of the young South Africans participating in the research felt that there was a payoff from working hard and being dedicated to the job. This finding is contrasted to a study by Scott, Nelson \& Scott (1988) which found that only $17 \%$ of American collegiate White students and $29 \%$ of American Hispanic students felt that "hard work' was a factor leading to workplace success. Interestingly, Table 5 shows that only a small percentage in every racial/ethnic respondent category, save for those classified as Coloured at $8.7 \%$, felt that affirmative action was an important factor leading to success on the job. The level of significance of this data is 0.2092 .

Table 5 Factors leading to success in the workplace (by ethnicity, observed frequency and percentage of respondents)

\begin{tabular}{lcccc}
\hline Factors & Black & White & Coloured & Total \\
\hline $\begin{array}{l}\text { Hard work and } \\
\text { dedication }\end{array}$ & 118 & 100 & 33 & 251 \\
& $79.2 \%$ & $71.4 \%$ & $71.7 \%$ & $74.9 \%$ \\
Timing and luck & 20 & 22 & 5 & 47 \\
& $13.4 \%$ & $15.7 \%$ & $10.9 \%$ & $14.0 \%$ \\
Help from higher-ups & 7 & 6 & 3 & 16 \\
& $4.7 \%$ & $4.3 \%$ & $6.5 \%$ & $4.8 \%$ \\
Playing politics & 2 & 7 & 1 & 10 \\
& $1.3 \%$ & $5.0 \%$ & $2.2 \%$ & $3.0 \%$ \\
Affirmative action & 2 & 5 & 4 & 11 \\
& $1.3 \%$ & $3.6 \%$ & $8.7 \%$ & $3.3 \%$ \\
\hline Total & 149 & 140 & 46 & 335 \\
& $100 \%$ & $100 \%$ & $100 \%$ & $100 \%$ \\
\hline
\end{tabular}

Rank ordering the factors in Table 6 by the largest percentage of respondents reveals that whereas Blacks and Coloureds felt that general economic conditions would be the prime factor hindering their career success. Whites ranked affirmative action policies first. A significant difference was found between the race groups with the chi-square value (88.148) significant at the 0.0000 level.

With respect to upward mobility through promotion, more than two-thirds of Black respondents felt that South African minorities (Whites, Coloureds, Asians) would stand an equal chance for promotions. White and Coloured respondents are less sure that there will be promotion equality. The percentages detailed in Table 7 illustrate these significant (chisquare value significant at the 0.0000 level) perceptual differences between the sample participants. It should be noted, however, that considerable general agreement (across racial or ethnic lines) was obtained from the questionnaire concerning equal treatment for: salary (question 22) and assigned job responsibility (question 24). With regards to opportunity to reach executive levels (question 25), there was general agreement between Black and White respondents, but the majority of Coloured respondents felt a lack of equal opportunity for minorities to become executives. Women (regardless of their

Table 6 Factors that hinder success in the workplace (by ethnicity, observed frequency and percentage of respondents)

\begin{tabular}{lcccc}
\hline Factors & Black & White & Coloured & Total \\
\hline General economic conditions & 61 & 44 & 14 & 119 \\
& $43.6 \%$ & $32.1 \%$ & $31.1 \%$ & $37.0 \%$ \\
Lack of jobs in chosen career field & 15 & 7 & 6 & 28 \\
& $10.7 \%$ & $5.1 \%$ & $13.3 \%$ & $8.7 \%$ \\
Affirmative action policies & 2 & 57 & 6 & 65 \\
Competition from others & $1.4 \%$ & $41.6 \%$ & $13.3 \%$ & $20.2 \%$ \\
Insufficient preparation for job field & 10 & 1 & 0 & 11 \\
& 24 & 20 & 10 & 54 \\
Lack of determination or drive & $17.1 \%$ & $14.6 \%$ & $22.2 \%$ & $16.8 \%$ \\
& 19 & 6 & 8 & 33 \\
Other hindering factors & $13.6 \%$ & $4.4 \%$ & $17.8 \%$ & $10.2 \%$ \\
\hline Total & 9 & 2 & 1 & 12 \\
\hline & $6.4 \%$ & $1.5 \%$ & $2.2 \%$ & $3.7 \%$ \\
\hline
\end{tabular}

Table 7 Equality for Promotion for Whites, Coloureds and Asians (by observed frequency and percentage of respondents)

\begin{tabular}{lcccc}
\hline Equality & Black & White & Coloured & Total \\
\hline Equal chance & 100 & 53 & 20 & 173 \\
& $69.4 \%$ & $38.1 \%$ & $43.5 \%$ & $52.6 \%$ \\
No equal & 44 & 86 & 26 & 156 \\
& $30.6 \%$ & $61.9 \%$ & $56.5 \%$ & $47.4 \%$ \\
\hline Total & 144 & 139 & 46 & 331 \\
& $100 \%$ & $100 \%$ & $100 \%$ & $100 \%$ \\
\hline
\end{tabular}


race or ethnicity) were generally viewed as having equal opportunity in terms of salary, promotion, responsibility, and becoming an executive (see questions 26 and 29 of the research instrument in the appendix).

Without question, affirmative action plays a major role in the thinking of many of the young people participating in this research project. This can be seen in the responses detailed in Table 8 where the chi-square value is significant at the 0.000 level. The question ( 32 in the research instrument) posed was: 'Do you feel that affirmative action policies (as you know them) will help, hurt, or make no difference to you in terms of the number of job opportunities available to you after completing your degree?' White and Coloured students perceive that affirmative action policies will limit their job opportunities after they have earned their university degrees. This is in sharp contrast to the majority of Black participants in this study who feel that they will be helped as a result of affirmative action.

\section{Conclusions}

Affirmative action is an issue which has attracted much debate and research, but the perceptions of university students have been neglected. The record of research conducted to date on affirmative action does not indicate any focus on students and their perceptions of affirmative action, yet university students are an important 'futuristic indicator' of societal perspectives. The aim of this research was therefore to conduct an initial investigation into student perceptions of affirmative action and the perceived effect it may have on their prospects of employment.

The major conclusions drawn from this study of university commerce students are that:

1. They view the factors likely to limit their workplace success differently: general economic conditions (Blacks and Coloureds), and affirmative action (Whites).

2. Most students feel that South African racial/ethnic minorities (Whites, Asians and Coloureds) will have opportunities equal to those of Blacks in terms of job salary and responsibility. Most White students, however, do not believe that the situation will be the same in respect of opportunities for promotion and most Coloured students do not believe that racial/ethnic minorities will have opportunities equal to those of Blacks to reach executive status.

3. Most students feel that women (regardless of race or eth-

Table 8 Impact of affirmative action on job opportunities (by ethnicity, observed frequency and percentage of respondents)

\begin{tabular}{lcccc}
\hline Impact & Black & White & Coloured & Total \\
\hline Help & 79 & 2 & 15 & 96 \\
& $54.1 \%$ & $1.4 \%$ & $32.6 \%$ & $28.8 \%$ \\
Hur & 13 & 123 & 17 & 153 \\
& $8.9 \%$ & $87.2 \%$ & $37.0 \%$ & $45.9 \%$ \\
No difference & 54 & 16 & 14 & 84 \\
& $37.0 \%$ & $11.3 \%$ & $30.4 \%$ & $25.2 \%$ \\
\hline Total & 146 & 141 & 46 & 333 \\
& $100 \%$ & $100 \%$ & $100 \%$ & 100 \\
\hline
\end{tabular}

nicity) will have equality of opportunity with men in the workplace for salary, promotion, responsibility, and the chance to become an executive.

4. A large majority (ranging from $88.5 \%$ to $93.5 \%$ ) of all racial/ethnic groups agrees with the statement: 'It should be illegal for any employer to discriminate against any person with regard to his/her race, colour, religion, gender, age, disability, or national origin'.

5. A small majority of Blacks feels that affirmative action will help the group in terms of job opportunities. The vast majority $(87.2 \%)$ of Whites feels, however, that affirmative action will be a negative, discriminatory factor in terms of job opportunities. Coloureds are fairly split between affirmative action helping, discriminating against them, or making no difference to them.

6. A majority of all racial/ethnic groups feels that South Africa is headed in the right direction.

University students do have perceptions regarding affirmative action and, as the 'futuristic indicator' of societal perspectives, these student perceptions need to be considered by policy makers. Since this research was undertaken primarily as an initial investigation, it is felt that further research needs to be conducted into the effect of student perceptions of affirmative action and the perceived effect it may have on prospects of employment for graduates; and indeed on student motivation and commitment to studies at universities in South Africa.

\section{Notes}

1. Trevor Amos administered the questionnaire, collected and analysed the data set, conducted the literature search and revised the manuscript.

2. J. William Fulbright wrote the manuscript and reviewed relevant literature during his visit to South Africa (June-December 1995).

3. Judith Scott conceived the research topic and designed the research instrument during her visit to South Africa (JuneAugust 1995)

4. Edgars has defined 'Black' to include Black, Asian and Coloured people. In other words, people who have been historically discriminated against and denied opportunities because of past apartheid legislation.

5. Of the 352 total questionnaires administered, 13 were 'unusable' either because questionnaire values were missing or outside the range of the instrument.

\section{References}

Bowmaker-Falconer, Angus \& Horwitz, Frank. 1994. 'Enhancing competitiveness through strategic HR', People Dynamics, July: 15-20.

Bureau of Market Research. 1994. Socio-economic profile of the nine provinces in South Africa, 1994 - research report no. 207. Pretoria: University of South Africa, Faculty of Economics and Management Sciences.

Caldwell, David. 1995. 'Affirmative action: advantage to the disadvantaged?', $H R M, 11: 20-23$.

Collins, Deanne. 1994. 'Affirmative action tokenism or transformation?', SA Labour Bulletin, 18: 40-45.

Daily Dispatch. 1995. 'South Africa's community'. September 2: 12.

Davies, Rob, O'Meara, Dan \& Dlamini, Sipho. 1988. The struggle for South Africa: a reference guide. Volume Two. London: Zed Books Ltd., p.52. 
Edgars Stores Limited. 1995. Affirmative action policy (issued by the corporation).

Enterprise. 1992. 'Affirmative action increases group conflicts'.

Financial Mail. 1995. 'Affirmative action: Asmal gets cracking', 137: 46.

Financial Mail. 1994. 'Apartheid is gone, but its destructive effects still haunt society. Investment in South Africa: a survey', September 30: 6 .

Historic Documents of 1993. 1994. South African Constitution. Washington: U.S. Library of Congress, pp. 1008-10030.

Mail \& Guardian. 1995. 'More affirmative action', August 25-31: B1.

Mbigi, Lovemore \& Maree, Jenny. 1995. UBUNTU: the spirit of African transformation management. Randburg: Knowledge Resources.

Scott, C., Richard, Nelson, James, A. \& Scott, Judith D. 1988. 'Perceptions of work: Anglo vs. Hispanic', Southwest Journal of Business and Economics, V: 18-26.

South African Chamber of Business (SACOB). 1995. A SACOB policy on affirmative action. Auckland Park: The South African Chamber of Business.

South African Institute for Race Relations. 1994. Race relations survey, 1993/1994. Johannesburg: South African Institute for Race Relations.

Weekend Post. 1995. 'SA can't afford an exodus of engineers', August 5: 2.

Wilson, Francis \& Ramphele, Mamphela. 1989. Uprooting poverty: the South African challenge. Cape Town: David Philip Publishers: pp. 17-18.

\section{Appendix 1}

\section{Research questionnaire}

Purpose: The purpose of this research instrument is to gather a data base for a research project. This questionnaire will be administered to a sample of business administration students in the Republic of South Africa (RSA) and the United States of America (USA).

Instructions: Please indicate your responses on this questionnaire by CIRCLING the response that BEST characterizes you and your feelings/beliefs. After completion, please return this questionnaire to your classroom instructor. Thank you for participating in this research project.

1. Gender:
a. male
b. female

2. Age:
a. $17-24$
b. $25-30$
c. $31-36$
d. 37 or older

3. Ethnicity:
a. black
b. white
c. coloured
d. Asian
e. other (specify)

4. Educational classification:
a. first year
b. second year
c. third year
d. honours

\section{Major area of study:}
a. management
b. accounting
c. info systems
d. economics
e. law
f. psychology
g. other (specify)

6. Approximate annual income of the household in which you grew up:
a. Above R266.000
b. R179.000-R265.000
c. R125.000-R178.000
d. R89.000-R 124.000
e. $R 64.000-R 89.000$
f. R35.000-R63.000
g. R18.000-R34.000
h. Less than R18.000

7. The occupation of the head of the household in which you grew up:
a. professional (law, medicine, etc.)
b. corporate business (salaried management)
c. owns small business/shop
d. owns farm
e. government employee (includes military)
f. education (teacher, lecturer, professor, etc.)
g. hourly wage earner
h. other (specify)

8. Does the head of the household in which you grew up hold a university degree?
a. yes
b. no

9. After completing your university degree, what occupation or career do you plan to pursue:
a. professional (law, medicine, etc.)
b. corporate business (salaried management)
c. own small business/shop
d. own farm
e. government employee (includes military)
f. education (teacher or professor, etc.)
g. hourly wage earner
h. other (specify)

10. How do you view your future opportunities in the workplace?
a. no limits
b. excellent
c. moderate
d. fair
e. poor
f. virtually nil

11. Compared with your parent(s), do you feel you have the
a. same
b. more
c. less
d. don't know? opportunities that they had

12. What do you feel will be the greatest LIMITATION which could cause you NOT to be successful in your occupational choice? 
a. general economic conditions

b. career choice (lack of job opportunities in your field)

c. affirmative action programmrs and policies

d. competition from others

e. improper and/or insufficient preparation for field

f. lack of determination or drive on your part

g. other (specify)

13. Are you optimistic or pessimistic as to the number of jobs that will be available for you to consider after obtaining your degree?
a. I'm optimistic
b. I'm pessimistic

14. Do you believe that if you 'really put your heart into it' you can rise to whatever heights you desire in the workplace?

a. yes, there are no limits

b. no, there are too many other factors to block my way?

15. Do you feel that work in itself is rewarding?
a. yes
b. no

16. Do you feel that you hold the same views toward work as your parent(s)?

a. yes

b. no

17. Do you feel that as long as you do a good job and 'keep your nose clean' you will be recognized and promoted?

a. yes

b. no

18. Do you agree or disagree with the statement: 'People should place more emphasis on working hard and doing a good job than on what gives them personal satisfaction and pleasure'.
a. agree
b. disagree

19. Do you agree or disagree with the statement: 'The workplace is a 'dog eat dog' environment.
a. agree
b. disagree

20. Which factor do you feel will cause you or your co-workers to get ahead in the workplace?
a. hard work and dedication to the job
b. timing and luck
c. help from higher-ups
d. playing politics
e. affirmative action policies

21. Do you think it is likely nowadays for someone in this country to start out poor and become rich simply by working hard?
a. yes
b. no

Answer for questions 22-25. Do you feel that racial or ethnic MINORITIES (whites, coloureds, Asians) will, in future, stand an equal chance and opportunity in the following areas: 22. SALARY
a. equal chance
b. not an equal cjance

\section{PROMOTION \\ a. equal chance \\ b. not an equal chance}

24. RESPONSIBILITY

\author{
a. equal chance \\ b. not an equal chance \\ 25. BECOMING AN EXECUTIVE
a. equal chance
b. not an equal chance

Answer for questions 26-29. Do you feel that WOMEN (regardless of their race or ethnicity) will, in future, stand an equal chance and opportunity as men (belonging to their same race and ethnicity) in the following areas:

\section{SALARY}
a. equal chance
b. not an equal chance

27. PROMOTION
a. equal chance
b. not an equal chance

28. RESPONSIBILITY
a. equal chance
b. not an equal chance

29. BECOMING AN EXECUTIVE
a. equal chance
b. not an equal chance

30. Do you agree or disagree with the following statement: 'It should be illegal for any employer to discriminate (for job placement, promotion, training, etc.) against any person with regard to his/her race, colour, religion, gender, age, disability, or national origin.'
a. agree
b. disagree

31. Do you agree or disagree that there is a positive relationship between your success in higher education and your future success in the workplace?
a. agree
b. disagree

32. Do you feel that affirmative action policies (as you know them) will help, hurt, or make no difference to you in terms of the number of job opportunities available to you after completing your degree?
a. help
b. hurt
c. make no difference

33. In general, do you feel that the economic policies of this country's government is doing enough with respect to creating jobs
a. yes
b. no

34. In general, do you feel that this country is headed in the right direction?
a. yes
b. no

35. Do you agree or disagree that your ability to "climb the ladder of success' will be mainly determined on your personal attributes and your hard work?
a. agree
b. disagree 